\title{
Didelio oro užterštumo epizodų meteorologinės sąlygos Vilniuje
}

\section{Dainius Frišmantas,}

\section{Gintautas Stankūnavičius}

Vilniaus universitetas,

Geomokslu institutas,

Chemijos ir geomokslu fakultetas,

M. K. Čiurlionio g. 21/27,

03101 Vilnius, Lietuva

El.paštas: dainius.frismantas@chgf.stud.vu.lt; gintas.stankunavicius@chgf.vu.lt
Frišmantas D., Stankūnavičius G. Didelio oro užterštumo epizodų meteorologinès sąlygos Vilniuje. Geologija. Geografija. 2018. T. 5(1). ISSN 2351-7549.

Straipsnyje analizuojamos didelio oro užterštumo epizodų 20052016 m. meteorologinès sąlygos Vilniuje. Kietụjų dalelių $\left(\mathrm{KD}_{10}\right)$ koncentracijos duomenys buvo gauti iš Aplinkos apsaugos agentūros. Šiame tyrime didžiausias dèmesys skirtas meteorologèms sąlygoms, lemiančioms didesnes teršalų koncentracijas, îvertinti: vyraujančios oro pernašos atgalinès dalelès trajektorijos metodams ir atmosferos stabilumo kriteriju kaitos charakteristikai tiriamų epizodų metu. Iš viso buvo išanalizuota 10 epizodų. Jie atrinkti pagal didžiausias kietujų dalelių koncentracijas. Trimatis oro dalelès judejjimas žemiausiame atmosferos sluoksnyje (1 000 ir $925 \mathrm{hPa}$ izobariniuose lygiuose) pagal atstumą buvo suskirstytas ị tris kategorijas: lokalią, regioninę ir tolimają. Atmosferos stabilumas vertintas turbulencijos, paribio sluoksnio storio, Paskvilio stabilumo klasių ir oro temperatūros gradiento inversijos sluoksnyje rodikliais. Naudoti reanalizės duomenys: ERA-Interim, NCEP/NCAR ir NCEP/DOE.

Keturiais iš 10 atvejų nustatytas vienalytis oro srautas, penkiais atvejais nustatyti atgalinès trajektorijos krypčių nesutapimai (12,5\%) tarp ERA-Interim ir NCEP/NCAR bei NCEP/DOE reanalizių. Didelio oro užterštumo epizodais dažniausios pasikartojusios vẻjo kryptys buvo iš šiaures, pietų ir pietvakarių. Šios situacijos susijusios su mažų gradientų lauko (5 epizodai), anticiklono (4) ir ciklono šilto sektoriaus poveikiu (1). 2005 m., vyraujant pietų krypties vèjui, užfiksuota didžiausia kietuju dalelių ribinè koncentracija - $172 \mu \mathrm{g} / \mathrm{m}^{3}$ per $24 \mathrm{val}$.

Raktažodžiai: kietosios dalelès, atgalinè dalelès trajektorija, oro užterštumo epizodai, temperatūros inversija, atmosferos stabilumas

\section{IVADAS}

Orai - tai meteorologinių parametrų kompleksas, mažai kintantis sąlyginai trumpais laikotarpiais: nuo kelių valandų iki kelių parų. Vidutiniškai per metus Lietuvoje 221 diena būna su cikloninio ir 144 dienos su anticikloninio tipo cirkuliaciniais procesais (Galvonaite ir kt., 2013). Pastoviausi orai vyrauja anticiklonuose ar jų itakos zonose.
Šis atmosferos darinys daro didelę ittaką spinduliuotès balansui, oro taršai ir hidrologiniam ciklui, kuris veikia Žemès klimatą (Ioannidou, Yau, 2007). Tiriamųjų darbų apie anticiklonus ir jų poveikị teršalų sklaidai Lietuvoje yra labai mažai.

Dažnai pasitaikantis anticikloninès cirkuliacijos požymis - temperatūros inversija (toliau - TI). TI - atmosferos sluoksnis, kuriame oro temperatūra didèja kylant aukštyn (Ahrens, 
2008). Apatiniame troposferos sluoksnyje yra didžiausias meteorologiniu parametru kintamumas horizontalioje ir vertikalioje plotmèse. Šiame sluoksnyje susidaro priežeminès TI, kurių struktūra dar mažai ištirta, ypač urbanizuotose teritorijose ir poliariniuose rajonuose (Schnelle, Brown, 2002). Vilniuje tokių tyrimų nèra atlikta arba jie nèra publikuoti. TI lemia oro priemaišų (dujiniai teršalai, smulkios kietosios dalelès ir jų mišinys - aerozolis) kaupimąsi poinversiniame sluoksnyje. Taip pat TI yra susijusi su horizontalaus matomumo sumažejimu ir neigiamu poveikiu žmonių sveikatai, todèl TI ir jų lemiamų orų bei oro kokybès tyrimai yra aktualūs iki šiol. S. E. Manahanas (2000) teigia, kad nuo XX a. 3-iojo dešimtmečio mokslinèje literatūroje atsiranda informacijos apie TI kaip nepalankių teršalų sklaidos vieną pagrindinių sąlygų, kai susilpnejusi turbulencija ir pramonès išmetamosios dujos bei aerozoliai kaupiasi atmosferos priežemio sluoksnyje. Informacija apie inversijų susidarymo sąlygas (sinoptinę situaciją, jų aukštị, storị ir intensyvumą) gali labai pagerinti teršalų sklaidos prognozių kokybę ir tikslingą visuomenès informavimą apie pavojingas žmogaus sveikatai teršalų koncentracijas. J. Li su bendraautoriais (2014) nustate koreliacinị ryši tarp TI ir santykinai didesnès aerozolio koncentracijos prie žemès paviršiaus. Naktị, kai buvo susiformavusi spindulinè atvėsimo inversija, užfiksuota atitinkamai 49 ir $54 \%$ didesnè $\mathrm{NO}_{2}$ ir $\mathrm{KD}_{2.5}$ koncentracija. Nustatyta, kad anticiklonų centruose ir gūbriuose kaupiasi didžiausios teršalų koncentracijos, o ciklonų centruose ir slèniuose - mažiausios. Atitinkamai 23,7 ir 29,8 \% padideja teršalų koncentracija, kai anticiklonų centruose ir gūbriuose vyrauja inversija. Pačios stipriausios TI - tiek pakiliosios, tiek priežemio - formuojasi vykstant anticikloninei cirkuliacijai. Daug teršalų sklaidos matematinių modelių naudoja inversijų charakteristikas kaip vieną pagrindinių veiksnių, lemiančių staigius priemaišų koncentracijų pokyčius.

I Lietuvos teritoriją oro teršalai patenka iš vietinių arba tolimųjų pernašos šaltinių. Kietụjų dalelių (toliau - $\mathrm{KD}_{10}$ ) koncentracijos padidejimas ir jų ribinès vertès viršijimai yra susiję su tolimosiomis pernašomis. $\mathrm{KD}_{10}$ - tai kietųjų dalelių frakcija, kurių aerodinaminis skersmuo ne didesnis kaip 10 mikrometrų. Ribinè aplinkos oro užterštumo vertè - mokslinėmis žiniomis pagrịsta aplinkos oro užterštumo lygio vertè, kuri nustatyta siekiant išvengti kenksmingo poveikio žmoniu sveikatai ir (arba) aplinkai (Lietuvos Respublikos..., 2017). Oro tarša labai padideja vyraujant intensyviems anticiklonams žiemą, kai teršalai iš namų ūkių, transporto, energetikos įmonių kaupiasi poinversiniame sluoksnyje.

2016 m. A. Fortelis ir kt. tyrè 2009-2013 m. (lapkritčio-vasario mèn.) meteorologinių sąlygų ir oro užterštumo epizodų $\left(\mathrm{KD}_{10}\right)$ ryšį. Oro užterštumo epizodai susiformuodavo, kai vejjo greitis buvo $1-2 \mathrm{~m} / \mathrm{s}$, TI gradientas sieke $-3{ }^{\circ} \mathrm{C} / 100 \mathrm{~m}$, o kritulių nebuvo 7 paras. Aukšto slègio sritis dažniausiai lemia silpnai vejjuotą, be kritulių orą. Nustatytas glaudus ryšys tarp anticikloninès cirkuliacijos ir oro užterštumo epizodų Neapolyje, taip pat buvo apskaičiuotas glaudus atvirkščiai proporcingas ryšys tarp vejjo greičio ir $\mathrm{KD}_{10}$ koncentracijos $(r=-0,7)$. Vyraujant stipresniam nei $4 \mathrm{~m} / \mathrm{s}$ vejjo greičiui oro užterštumas dažniausiai neviršijo leistinos 24 val. $\mathrm{KD}_{10}$ ribinès vertès $\left(50 \mu \mathrm{g} / \mathrm{m}^{3}\right)$.

Atgalinès dalelès trajektorija (toliau - ADT) plačiai taikoma tyrimo analizè. Trajektorijų analizé - pagrindinis būdas išsiaiškinti atmosferos darinių pernašą. Trajektorijos raiška ir tikslumas priklauso nuo vèjo lauko dedamųų raiškos, skaičiavimo metodų ir meteorologinių charakteristikų (Hondula ir kt., 2009). L. Veriankaitès (2010) disertaciniame darbe buvo naudota atgalinès dalelès trajektorija remiantis HYSPLIT (NOAA) ir SILAM (Suomijos meteorologijos institutas) modeliais. ADT metodas buvo naudojamas tiriant 2004-2009 m. žiedadulkių koncentracijos ore cirkuliacinius procesus. ADT metodus taikè V. N. Matthaios ir kt. (2016), norèdami išsiaiškinti ekstremalių kietųjų dalelių $\left(>50 \mu \mathrm{g} / \mathrm{m}^{3}\right)$ koncentracijų ryši su tolimąja pernaša Graikijoje. $\mathrm{KD}_{10}$ buvo tirtas penkiuose skirtinguose Graikijos regionuose nuo $2009 \mathrm{~m}$. sausio iki $2011 \mathrm{~m}$. gruodžio mèn. ADT trajektorija buvo matuojama trijuose skirtinguose lygiuose kas 3 val.: 500, 1500 ir $3000 \mathrm{~m}$ virš žemès paviršiaus. Nustatyta, kad didžiausia $\mathrm{KD}_{10}$ koncentracija vyravo lapkričio-gruodžio mènesiais.

Oro kokybė urbanizuotose teritorijose priklauso nuo stacionarių ir mobilių taršos šaltinių emisijos bei nuo teršalų sklaidą lemiančių veiksnių: turbulencijos, temperatūros inversijos, vejjo parametrų, kritulių. Miestuose, kur daug ivvairių 
taršos šaltinių, palankias teršalų kaupimuisi sąlygas lemia anticiklonas, gūbrys ir mažų gradientu barinis laukas. Mažesniuose miestuose oro kokybè priklauso nuo vieno stambaus teršèjo. Oro užterštumas gali padidèti esant palankios krypties vejui, kuris teršalus perneša nuo gamyklos teršèjos link miesto (Bukantis ir kt., 2003).

Klasikiniame paribio sluoksnio meteorologijos vadovèlyje teigiama, kad paribio sluoksnis (toliau - PS) - tai vieta, kurioje dar jaučiama paklotinio paviršiaus sukelta trintis per turbulencinę sąmaišą (Stull, 2017). Šio sluoksnio storis naudojamas kaip pagrindinis parametras oro priemaišu modeliavimui. PS viršutineje dalyje yra pereinamasis sluoksnis tarp jo ir laisvosios atmosferos, kuris dažniausiai atitinka pakiliąją inversiją (Nemuc ir kt., 2012). Pakilioji inversija dèl žemyneigių oro srautų yra slegiama ir stumiama arčiau paklotinio paviršiaus, ir PS plonèja. Priežeminis PS apima $20-200 \mathrm{~m}$ storio atmosferos sluoksni. Nepastoviai stratifikuotoje atmosferoje turbulencija ir konvekcija gali išmaišyti apatinị $0,2-4,0 \mathrm{~km}$ sluoksni, o pastoviai stratifikuotoje atmosferoje turbulencinis sluoksnis niekada neviršija $500 \mathrm{~m}$ storio, todèl didelis oro užterštumas yra susijęs su aukštu slègiu, mažų gradientų laukų ir anticiklono gūbriais (Sillman, Samson, 1995; Stull, 2017).

B. Czernickis ir kt. (2016) tyrè atmosferos sąlygu poveikį vidutinèms ir ekstremalioms $\mathrm{KD}_{10}$ koncentracijoms Poznaneje (Lenkija, 2006-2013 m.). Didesnes $\mathrm{KD}_{10}$ koncentracijas lemia staigus oro temperatūros nukritimas $3{ }^{\circ} \mathrm{C}$, mažèjantis PS storis, vidutinis vejjo greitis $(\sim 1 \mathrm{~m} / \mathrm{s})$ ir pasikeitusi vejjo kryptis iš vakarų i rytus. Ši situacija yra susijusi su stiprejjančiu anticiklonu virš Rytų Europos ir silpnejjančiu Islandijos minimumu. Oro užterštumo epizodai užfiksuoti žiemą vyraujant blokuojantiems anticiklonams. E. Rimkus ir kt. (2006) tyrè meteorologinių veiksnių poveiki $\mathrm{KD}_{2.5}$ kaitai Preiloje. Nustatyta, kad šaltuoju metu laiku vidutine $\mathrm{KD}_{2.5}$ koncentracija $20-30 \%$ didesnè nei šiltuoju. Beveik $90 \%$ visų analizuojamų $\mathrm{KD}_{2.5}$ koncentracijos padidejimų susiję su aukštesnio slègo priežeminiais laukais $(>1013 \mathrm{hPa})$.

Tyrimo tikslas - meteorologinių sąlygų ịvertinimas didelio oro užterštumo epizodų metu (toliau - DUE) Vilniuje. Uždaviniai: 1) meteorologinių veiksnių poveikio teršalų koncentracijai ìvertinimas; 2) teršalų pernašos dalelès trajektorijos metodų analizé - oro dalelès trajektori- jų žemiausiame atmosferos sluoksnyje (1 000 ir $925 \mathrm{hPa}$ ) nustatymas naudojant mažos raiškos pakartotinès analizès duomenis bei advekcinių meteorologinių kintamųjų kaitos tyrimas.

\section{DUOMENYS IR METODIKA}

Tyrimo objektas - trimatis oro dalelès judejjimas žemiausiame atmosferos sluoksnyje (1 000 ir $925 \mathrm{hPa}$ standartiniuose izobariniuose lygiuose). Oro dalele - ìsivaizduojamas oro kūnas, kuriam gali būti priskirtos visos pagrindinès dinaminès ir termodinaminès atmosferos savybès (Chandrasekar, 2010). Oro dalelès trajektorijos nustatomos dažniausiai siekiant įvertinti oro masès (masių) raidą. Tokios trajektorijos leidžia diagnozuoti procesus, kurie tam tikromis sąlygomis gali veikti tame rajone esančias oro mases. Tikslus dalelès trajektorijos nustatymas susijęs su išsamia oro masiu raidos ir veiklos analize. ADT geriausiai parodo advekcinius meteorologinių kintamųju pokyčius laisvoje atmosferoje, kur trintis labai maža ir nèra didelių horizontalaus vejjo vertikalių poslinkių (Šauliené, Veriankaite, 2006; Godłowska ir kt., 2015).

Darbe naudotos ADT buvo gautos taikant trimati (3D) modeli (traj3d), kurio pagrindas yra dvimatis (2D) R. M. Lawo (1993) modelis, pirmą kartą aprašytas G. Perrino ir I. Simmondso darbe (1995). Detalų 3D trajektorijų skaičiavimo algoritmo aprašymą galima rasti V. Barraso ir I. Simmondso tyrime (2009). Daleles trajektorijos programine iranga (Parcel Trajectory Software) traj3d yra laisvai prieinama Melburno universiteto tinklalapyje (http://www.cycstats.org/ trajectories/trajhome.htm). Taip pat yra galimybe naudoti šią programą tiesiogiai iš NOAA Žemès sistemos tyrimų laboratorijos trajektorijų imitacijų tinklalapio (https://www.esrl.noaa.gov/psd/ cgi-bin/data/trajtool/traj.pl).

Vertikalus oro dalelès judejjimas nebuvo analizuotas tais atvejais, kai oro dalelès kilimo ar leidimosi amplitude neviršijo $20 \mathrm{hPa}$ per $30 \mathrm{va}-$ landų. Tokio intensyvumo vertikalūs judesiai paprastai neviršija modelio vertikalių judesių vidutinès paklaidos. Analizuoti slūgimo (judejimo) tempai, kurie yra susiję su priežeminių TI susidarymu arba raida. Netikslinga ADT metodą taikyti skaitmeninio modelio vertikaliuose lygiuose, artimuose modelio paklotiniam 
paviršiui, nes jie dažniausiai pasižymi dideliu šiurkštumu dèl augmenijos, neatitikimu tarp modelio ir realios topografijos bei kraštovaizdžio elementų. $1000 \mathrm{hPa}$ izobarinis lygis nenagrinèjamas, kai oro dalelè yra arti žemès paviršiaus. $925 \mathrm{hPa}$ izobarinio lygio aukštis skiriasi dèl oro masès savybių, tačiau dažniausiai svyruoja 600$800 \mathrm{~m}$ virš jūros lygio. Tai žemiausi galimi izobariniai lygiai naudojamuose modeliuose. Jie papildo vienas kitą - abu yra trinties sluoksnyje, tačiau vienas jo apačioje, kitas - viršuje. Šiame sluoksnyje horizontalus vejjas didejjant aukščiui sukasi $\mathfrak{i}$ dešinę ir stiprejja iki trinties sluoksnio viršutinès ribos, kol netampa artimas geostrofiniui. Taigi dalelès pernaša šiuose sluoksniuose skiriasi. Vienintelis $1000 \mathrm{hPa}$ lygio trūkumas, kad jis atskirais atvejais (kai paviršiaus slègis $<1000 \mathrm{hPa}$ ) gali būti labai arti paklotinio paviršiaus arba net žemiau jo.

NOAA ESRL trajektorijų imitacijų tinklapyje i̇diegta programinè įranga naudoja kelių reanalizių duomenis trajektorijų ir jų charakteristikų skaičiavimams. Visos jos yra palyginti mažos erdvinès raiškos duomenų bazès: NCEP/NCAR (toliau - NN1) (Kalnay ir kt., 1996), NCEP/DOE (toliau - NN2) (Kanamitsu ir kt., 2002) ir ERAInterim (toliau - ERA) reanalizès. Visos jos reprezentuoja globalaus masto duomenis, tačiau su skirtinga erdvine / laikine raiška, apdorotos skirtingais modeliais ir naudoja skirtingus tipus ir pradinių ịvesties duomenų kiekį. Jų charakteristikos pateiktos 1 lenteleje. NN1 ir NN2 priklauso vienai JAV mokslo organizacijai - NOAA NCEP. Nei vienas iš šių reanalizès duomenų bazių $100 \%$ neatitinka realios atmosferos cirkuliacijos, todèl naudojant skirtingas duomenų bazes galima geriau išsiaiškinti modeliuojamo oro srauto neapibrèžtumus. ERA priklauso Europos vidutinès trukmès prognozių centrui (ECMWF) ir duomenų bazès teikiami duomenys NOAA ESRL trajektorijų imitacijų tinklalapyje pasiekiami šiuo metu iki 2014 m. pabaigos (Dee ir kt., 2011). Naudojant skirtingas reanalizes oro dalelès trajektoriju imitacijai buvo siekiama nustatyti trajektorijų parametrų skirtumus tarp modelių duomenų analizuojamais laikotarpiais.

Tyrimo laikotarpis apima 2005-2016 metus. Sumodeliuota 10 ADT epizodų, kurie pasirinkti pagal didžiausias $\left(\mathrm{KD}_{10}\right)$ reikšmes Vilniuje (2 lentelè). $\mathrm{KD}_{10}$ viršytos leistinos normos $\left(50 \mu \mathrm{g} / \mathrm{m}^{3}\right)$ buvo gautos iš Aplinkos apsaugos agentūros darbuotojuc ir interneto tinklalapio <http://oras. gamta.lt/cms/index $>$. Oro užterštumo monitoringo duomenys yra renkami šiose Vilniaus oro kokybès tyrimu stotyse: Senamiesčio $\left(54,68^{\circ} \mathrm{N}\right.$, $25,29^{\circ}$ E), Lazdynų $\left(54,69^{\circ} \mathrm{N}, 25,21^{\circ} \mathrm{E}\right)$, Žirmūnų $\left(54,72^{\circ} \mathrm{N}, 25,23^{\circ}\right.$ E) ir Savanorių pr. $\left(54,67^{\circ} \mathrm{N}, 25,25^{\circ} \mathrm{E}\right)$. Galutinis ADT taškas buvo virš Vilniaus miesto (erdvinio taško koordinatès $54,63^{\circ} \mathrm{N}, 25,28^{\circ} \mathrm{E}$ ). Šios koordinatès geriausiai atitinka Vilniaus miesto padèti ir skirtingu modelių koordinačių tinklelio taškus.

Išvesties duomenys buvo apdorojami naudojantis ESRI ArcGIS programos ArcMap 10.4 versija, kuria buvo nubraižyti kiekvienos konkrečios ADT nueitas kelias iki Vilniaus per 30 valandų. Nustatytos dominuojančios kryptys, ilgiausios trajektorijos ir ADT zoniškumas Vilniuje. Žemèlapiuose sutartiniais ženklais pavaizduoti priežeminių barinių darinių centrai. 10 ADT situacijų

1 lentelè. Pakartotinių reanalizių, naudojamų NOAA ESRL trajektorijų imitacijoms, charakteristikos

Table 1. Characteristics of reanalyses in NOAA ESRL trajectory simulations

\begin{tabular}{|c|c|c|c|c|c|}
\hline \multirow{2}{*}{\multicolumn{2}{|c|}{$\begin{array}{l}\text { Pavadinimas } \\
\text { Name }\end{array}$}} & \multirow{2}{*}{$\begin{array}{l}\text { Organizacinè } \\
\text { priklausomybè } \\
\text { Organisational } \\
\text { dependence }\end{array}$} & \multicolumn{2}{|c|}{$\begin{array}{l}\text { Duomenų erdvès ir laiko padengimas } \\
\text { Spatial and temporal resolution }\end{array}$} & \multirow{2}{*}{$\begin{array}{l}\text { Duomenų bazès erdvinè } \\
\text { raiška (laipsniais platumos } \\
\text { ir ilgumos) } \\
\text { Spatial resolution (degree } \\
\text { of longitude and latitude) }\end{array}$} \\
\hline & & & Laiko intervalai & Erdvinè aprèptis & \\
\hline $\begin{array}{c}\text { NCEP/ } \\
\text { NCARI(R1) }\end{array}$ & NN1 & NCEP/NCAR & 1948 - dabar / now & Globali / Global & $2,5 \times 2,5$ ir $2,0 \times 2,0$ \\
\hline $\begin{array}{l}\text { NCEP/DOE } \\
\text { AMIP-II(R2) }\end{array}$ & NN2 & NCEP/DOE & 1979 - dabar / now & Globali / Global & $2,5 \times 2,5$ \\
\hline $\begin{array}{l}\text { ECMWF } \\
\text { Interim }\end{array}$ & ERA & ECMWF & 1979-2014 & Globali / Global & $\begin{array}{l}0,75 \times 0,75 \\
\text { ir mažesnè / and lower }\end{array}$ \\
\hline
\end{tabular}


2 lentelè. Datos ir $\mathrm{KD}_{10}$ koncentracijos reikšmès, kai Vilniaus oro kokybės tyrimų stotyse buvo užfiksuoti 24 val. ribinès vertès viršijimai. $\mathrm{KD}_{10} 24$ val. ribinè vertė $-50 \mu \mathrm{g} / \mathrm{m}^{3}$. ${ }^{*}-2005 \mathrm{~m}$. stotis buvo Žvèryno rajone (ne Savanoriu pr.)

Table 2. Dates of peak pollution episodes (PPE), when the fine particulate matter $\left(P M_{10}\right)$ daily concentration exceeded limit values in Vilnius air quality stations. Daily concentration limit value is $50 \mu \mathrm{g} / \mathrm{m}^{3}$, * ${ }^{*}$ in 2005 the Savanoriu pr. station was located at the Žverynas municipal district

\begin{tabular}{|c|c|c|c|c|c|c|c|c|c|c|}
\hline Nr. / No. & $\mathbf{I}$ & II & III & IV & v & VI & VII & VIII & IX & $\mathrm{x}$ \\
\hline Data / Date & 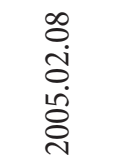 & 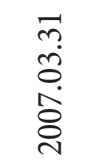 & 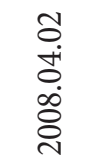 & 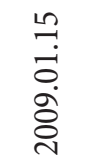 & $\begin{array}{l}\stackrel{2}{?} \\
\dot{0} \\
\stackrel{0}{0} \\
\stackrel{0}{\circ}\end{array}$ & 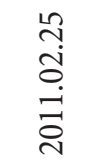 & 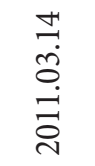 & 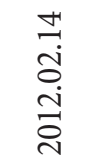 & 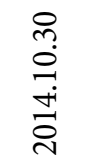 & $\begin{array}{l}\text { ठ } \\
\dot{0} \\
\dot{0} \\
\stackrel{0}{0}\end{array}$ \\
\hline Senamiestis & 110,2 & 112,7 & 96,2 & 87,4 & 140,5 & 137,4 & 98,4 & 114,1 & 114,3 & 158,5 \\
\hline Lazdynai & 70,4 & 80,1 & 80,1 & 87,8 & 101,8 & 68,0 & 67,8 & 106,2 & 88,6 & 107,7 \\
\hline Žirmūnai & 156,8 & 122 & 154,3 & 104,7 & 115,8 & 113,6 & 128,0 & 110,0 & 132 & 141,6 \\
\hline Savanorių pr.* & $172,4^{*}$ & 109,4 & 95,9 & 98,1 & 152,4 & 91,1 & 100,7 & 103,2 & 102,1 & 124,0 \\
\hline
\end{tabular}

buvo suskirstyta $\mathfrak{i}$ kategorijas pagal ilgị, o trajektorijų ilgiai - pagal tris buferinès zonos kategorijas: $\mathrm{S}<300 \mathrm{~km}$ (lokali), M $300<500 \mathrm{~km}$ (regioninè), L $>500 \mathrm{~km}$ (tolimoji pernaša). Trajektorijos ilgiai buvo priskirsti atitinkamai kategorijai, jei bent du iš trijų modelių nurodè tą patị teritorijos plotą (3 lentelè).

Atmosferos stabilumui ịvertinti buvo naudojami: vertikalios sąmaišos (turbulencijos), PS storio, Paskvilio stabilumo klasès ir oro temperatūros gradientas oro temperatūros inversijose (toliau - Г). Paskvilio stabilumo klasių interpretacija pagal NOAA prieinama internete $<$ https://ready. arl.noaa.gov/READYpgclass.php/>. Buvo naudojama globali trimate atmosferos kintamųjų duomenų bazé - sistema GDAS (angl. Global Data Assimilation System), jos skaitmeninès atmosferos vertikalios struktūros duomenys, kurie laisvai pasiekiami iš NOAA Atmosferos tyrimų laboratorijos tinklalapio (https://ready.arl.noaa.gov/READYamet.php).

GDAS duomenų erdvinè raiška yra: horizontali $-0,5 \times 0,5^{\circ}$ platumos ir ilgumos; vertikali -55 hibridiniai sigma (ৎ) - slègio (P) lygiai. Iš šio archyvo naudoti vejo greičio $(\mathrm{m} / \mathrm{s})$, oro temperatūros $\left(\mathrm{T}^{\circ} \mathrm{C}\right)$, vertikalios sąmaišos / turbulencijos koeficiento $\left(\mathrm{m}^{2} \mathrm{~s}^{-2}\right)$, paribio sluoksnio storio $(\mathrm{m})$ ir Paskvilio stabilumo klasių išvesties duomenys. Artimiausias erdvinis taškas Vilniaus miesto koordinatèms yra $54,63^{\circ} \mathrm{N} 25,28^{\circ} \mathrm{E}$; šio taško aukštis GDAS sistemoje $-156 \mathrm{~m}$ virš jūros lygio. Pagal vertikalų oro temperatūros profilị buvo skaičiuojami oro temperatūros vertikalūs gradientai $(\Gamma)$ inversiniuose sluoksniuose. Remiantis 2 lenteleje pateiktomis didžiausiomis $\mathrm{KD}_{10}$ reikšmèmis, Vilniuje buvo nubrèžti kaitos grafikai, vaizduojantys per 24 val. kintantị vertikalios sąmaišos intensyvumą, paribio sluoksnio stori, Paskvilio stabilumo klasę, oro temperatūrą ir vejjo greitị.

Kiekvienos paros buvo nustatyti vyraujantys bariniai dariniai slègio jūros lygyje (4 lentelè): $\mathrm{H}$ - anticiklonai $(\mathrm{H}$, ang. k. High), ngH - mažų gradientu laukas (nongradiental High pressure), C - ciklonai (Cyclone) vidurineje troposferoje $500 \mathrm{hPa}$ (aukštuminiai anticiklonai (uH nuo termino upper High) / gūbriai (uR nuo upper Ridge), aukštuminiai

3 lentelè. Didelio užterštumo epizodų ADT priskyrimas atitinkamai (S, M, L) trajektorijos ilgio kategorijai

Table 3. Categories of the length of backward air trajectories (S, M and L) in different air pollution episodes: I-X

\begin{tabular}{|c|c|c|c|c|c|c|c|c|c|c|c|}
\hline Reanalizè / Reanalysis & Nr. / No. & I & II & III & IV & $\mathbf{V}$ & VI & VII & VIII & IX & $\mathbf{X}$ \\
\hline ERA & \multirow{3}{*}{$\begin{array}{c}\text { Kategorija } \\
\text { Category }\end{array}$} & $S$ & $\mathrm{M}$ & $\mathrm{L}$ & $\mathrm{M}$ & $\mathrm{L}$ & $S$ & $\mathrm{M}$ & $\mathrm{M}$ & $\mathrm{L}$ & - \\
\hline NN1 & & $S$ & $\mathrm{~L}$ & $\mathrm{~L}$ & M & $\mathrm{L}$ & M & S & M & $\mathrm{M}$ & M \\
\hline NN2 & & $S$ & $\mathrm{M}$ & $\mathrm{L}$ & M & $\mathrm{L}$ & $\mathrm{M}$ & S & $S$ & $\mathrm{M}$ & M \\
\hline
\end{tabular}


4 lentelè. Meteorologinių parametrų duomenys: didelio oro užterštumo epizodų (I-X) paribio sluoksnio storis (PS), didžiausia TI, Paskvilio stabilumo klasė ir vėjo greitis (W), priežeminio lauko sinoptinè situacija (SLP), geopotencialaus aukččio $500 \mathrm{hPa}$ lygyje lauko struktūra (H500), hidroterminio lauko sąlygos - santykinẻ drègmė $700 \mathrm{hPa}$ lygyje (RH700) ir oro temperatūra $850 \mathrm{hPa}$ lygyje (T850)

Table 4. Meteorological data during air pollution peak episodes (particular time tick). The serial number of the peak pollution episodes (I-X): boundary layer height (PS), peak temperature inversion, Pasquill stability classes (A-G), wind speed (W), weather patterns according to sea level pressure (SLP) field and geopotencial height at $500 \mathrm{hPa}$ (H500) field, hydrothermical conditions in lower troposphere: relative humidity range at $700 \mathrm{hPa}(\mathrm{RH} 700)$ level and air temperature at $850 \mathrm{hPa}$ level (T850)

\begin{tabular}{c|c|c|c|c|c|c|c|c|c}
\hline $\begin{array}{c}\text { Nr. } \\
\text { No. }\end{array}$ & $\begin{array}{c}\text { Laikas / Time } \\
\text { (UTC) }\end{array}$ & PS, $\mathbf{m}$ & TI, ${ }^{\circ} \mathbf{C}$ & $\begin{array}{c}\text { Paskvilio klasés } \\
\text { Pasquill classes }\end{array}$ & W, m/s & SLP & H500 & T850, ${ }^{\circ} \mathbf{C}$ & RH700, \% \\
\hline I & 6 & 111 & $-1,3$ & E & 3,7 & H & uH & $-4 ;-6$ & $30-60$ \\
\hline II & 0 & 60 & $-2,3$ & G & 1,3 & ngH & uH & $0 ;-2$ & $70-85$ \\
\hline III & 18 & 112 & $-0,4$ & D & 3,4 & ngH & uH & $-1 ; 1$ & iki 90 \\
\hline IV & 0 & 135 & $-0,5$ & E & 4,4 & H & uT & $-15 ;-18$ & iki 80 \\
\hline V & 0 & 135 & $-1,5$ & E & 1,8 & H & uC & $-12 ;-15$ & iki 95 \\
\hline VI & 6 & 95 & $-0,5$ & E & 4,4 & H & uT & $-12 ;-10$ & $70-90$ \\
\hline VII & 21 & 52 & $-1,5$ & G & 2,6 & C & uR & $0 ; 5$ & iki 90 \\
\hline VIII & 6 & 126 & $-0,5$ & D & 3,5 & ngH & uT & apie -12 & $60-90$ \\
\hline IX & 3 & 130 & $-0,9$ & D & 6,1 & ngH & uT & $2 ; 8$ & $25-50$ \\
\hline X & 6 & 51 & $-0,4$ & E & 2,6 & ngH & uT & $-14 ;-10$ & $30-60$ \\
\hline
\end{tabular}

ciklonai (C nuo upper Cyclone) / aukštuminiai slèniai (uT nuo upper Trough) ir apatinès troposferos hidroterminio lauko struktūra (oro temperatūros kaita 850 hPa lygyje ir santykinè drègmė $700 \mathrm{hPa}$ lygyje) galingiausių inversijų metu. Atmosferos frontų, barinių darinių ar jų dalių itakai nustatyti buvo naudojami trys skirtingi šaltiniai: KNMI - Karališkojo Nyderlandų meteorologijos instituto orų žemèlapių schemos, DWD - Vokietijos orų tarnybos sinoptiniai žemèlapiai ir UKMO - Jungtinès Karalystès orų tarnybos sinoptinès schemos.

\section{REZULTATAI}

\section{Temperatūros inversijos ir paribio sluoksnis}

Nustatyta, kad septyniuose iš 10 stipriausių $\mathrm{KD}_{10}$ koncentracijos epizodų temperatūros inversijos formavosi naktimis arba rytais (tarp vidurnakčio ir 6 val. ryto) (4 lentelè). Ploniausias paribio sluoksnio storis $(<100 \mathrm{~m})$ buvo užfiksuotas keturiuose (II, VI, VII, X) iš 10 epizodų, o trijuose iš šių keturių (II, VI, X) epizodų virš Lietuvos teritorijos vyravo mažų gradientų laukas, VII epizodo metu - ciklono šiltasis sektorius. Taip pat dviejuose iš keturių (II, VII) epizodų vyravo labai stabilios atmosferos sąlygos pagal Paskvilio stabilu- mo klasifikaciją. Tais pačiais metais (II ir VII situacijos) buvo susidarę pačios stipriausios priežemio temperatūros inversijos, kai TI gradientas buvo atitinkamai $\Gamma=-2,3$ ir $-1,5{ }^{\circ} \mathrm{C} / 100 \mathrm{~m}$ (1 pav. II). Kitų dviejų epizodų metu (VI ir X) vyravo vidutiniškai stabilios sąlygos, nes nenustatyta stipriu TI (gradientai atitinkamai VI ir X situacijoje buvo $\Gamma=-0,5$ ir $-0,4{ }^{\circ} \mathrm{C} / 100 \mathrm{~m}$ ). Likusiais atvejais (6), kai vyravo stipri TI, PS neviršijo $150 \mathrm{~m}$.

2009 ir 2010 m. IV ir V epizodų laikotarpiais, atitinkamai, naktimis susidarius TI ir esant vienodam PS (135 m), išmatuotas oro užterštumas skirtinguose miesto rajonuose buvo nevienodas. Ypač didelis skirtumas $\left(54 \mu \mathrm{g} / \mathrm{m}^{3}\right)$ nustatytas Savanoriuc prospekte, nors Paskvilio stabilumo klasè abiejuose epizoduose rodè vidutiniškai stabilias atmosferos sąlygas $(E)$. Šj skirtumą lèmé TI, kuri buvo intensyvesnè $\mathrm{V}$ epizode $\left(\Gamma=-1,5{ }^{\circ} \mathrm{C} / 100 \mathrm{~m}\right)$, o IV epizode TI buvo silpnesnè $\Gamma=-0,5{ }^{\circ} \mathrm{C} / 100 \mathrm{~m}$ ( 1 pav. IV ir $\mathrm{V}$ (a)). Be to, turbulencijos sąmaišos koeficientas $\mathrm{V}$ epizode buvo 17 kartų mažesnis, palyginti su IV. Šiame epizode vidutinis vejjo greitis TI sluoksnyje buvo $4,4 \mathrm{~m} / \mathrm{s}$, o V epizode - $1,8 \mathrm{~m} / \mathrm{s}$ ( 1 pav. IV ir V (b)). IV epizode vyravo mažų gradientų laukas, pereinantis ị anticikloną, o V epizode - anticiklonas. 


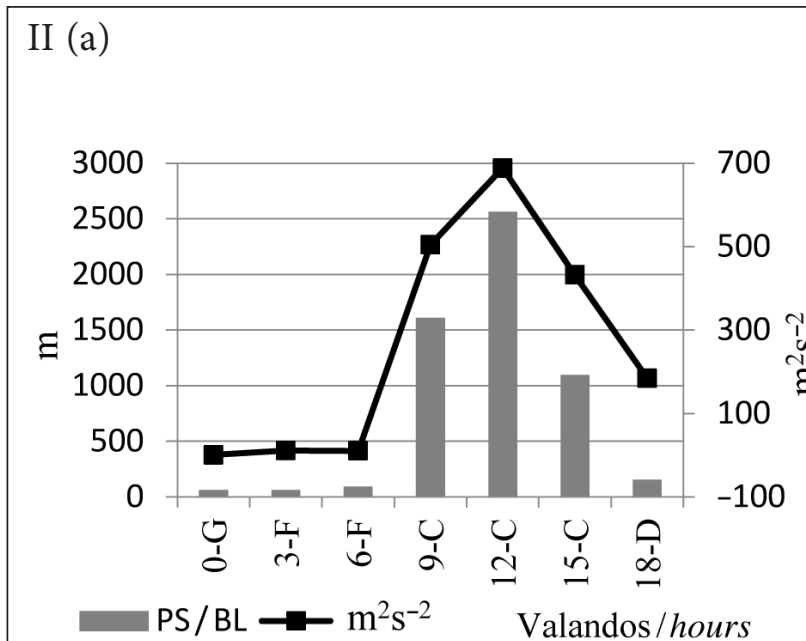

II (b)

IV (a)
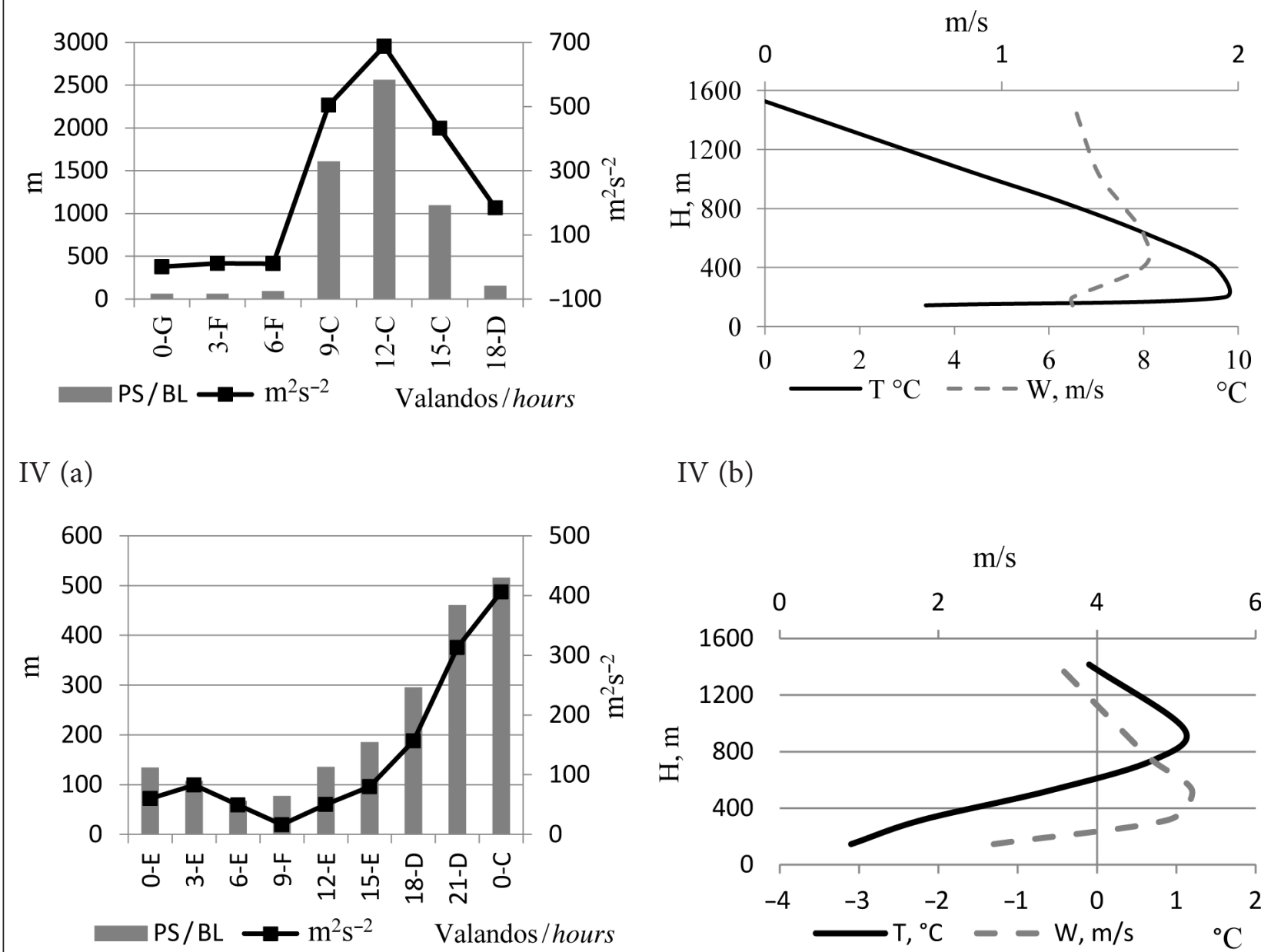

IV (b)

$\mathrm{V}(\mathrm{a})$

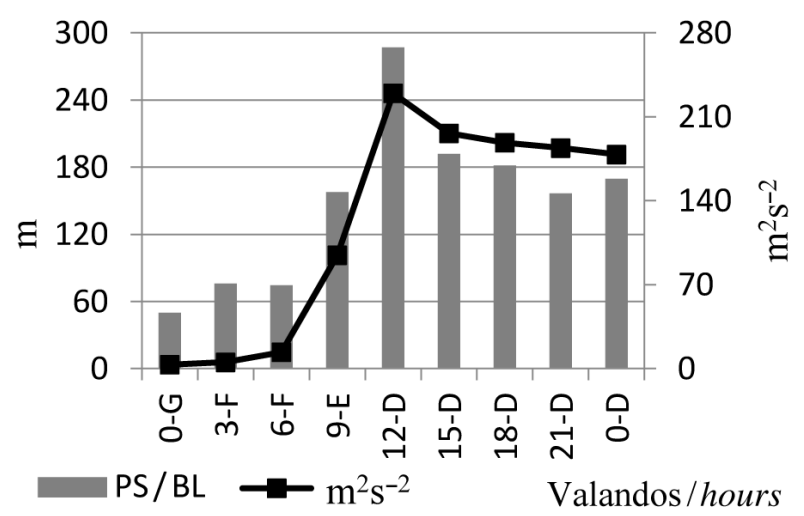

$\mathrm{m} / \mathrm{s}$

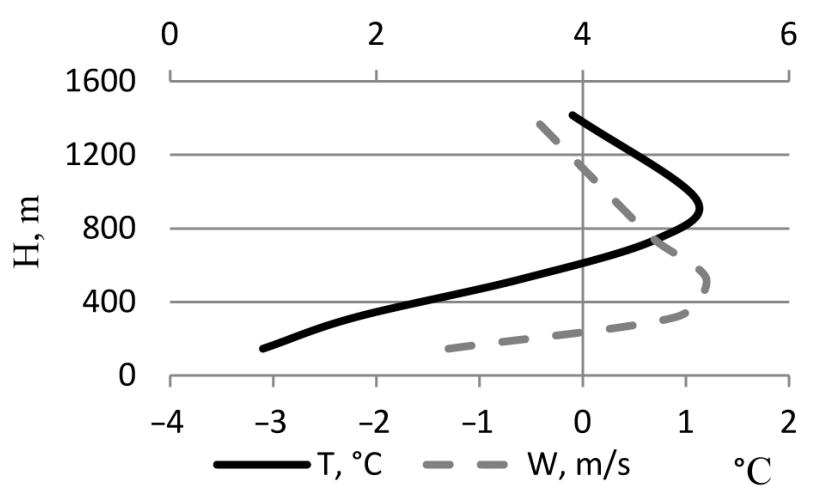

$\mathrm{V}(\mathrm{b})$

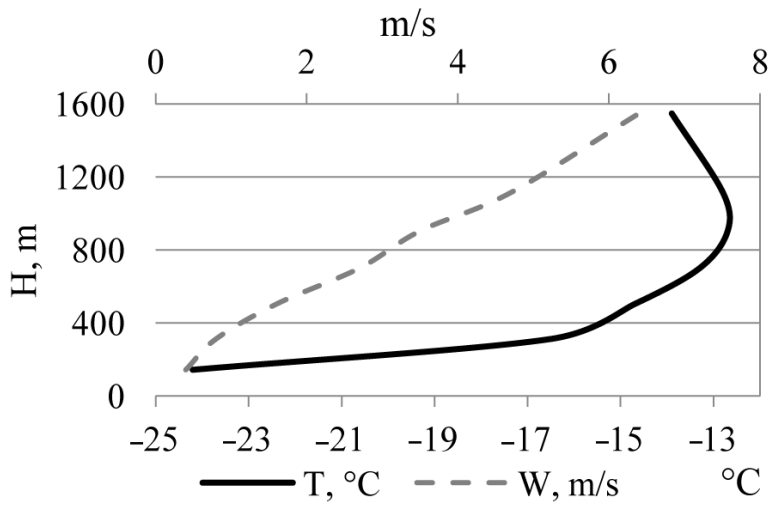

1 pav. Meteorologiniai parametrai padidintos taršos epizodų metu: a) paribio sluoksnio (PS) storis (stulpeliai) ir vertikalios oro sąmaišos koeficientas (juoda stora linija), raidès prie valandų nurodo Paskvilio stabilumo klasę; b) oro temperatūros (juoda stora linija) ir vèjo greičio (pilka punktyrinė linija) vertikalus pasiskirstymas II, IV ir V epizodais

Fig. 1. Meteorological parameters at peak pollution episodes: a) boundary layer (BL) depth ( $m$, columns) and vertical mixing coefficient (black solid line) in B, D and E peak pollution episodes. Letters near UTC hours on $\times$ axis show Pasquill stability class; b) air temperature (black solid line) and wind speed (grey dashed line) in II, IV and V peak pollution episodes 
2008 ir 2012 m. III ir VIII didelio oro užterštumo epizodų laikotarpiais atmosferos stabilumo parametrai buvo panašūs, tačiau $\mathrm{KD}_{10}$ koncentracija skirtinga, ypač Žirmūnų stotyje. Skirtumas buvo didesnis negu $44 \mu \mathrm{g} / \mathrm{m}^{3}$. Abiejuose DUE vyravo neutralios atmosferos sąlygos $(D)$ ir mažų gradientų laukas. TI gradientas atitinkamai III ir VIII atvejais buvo $\Gamma=-0,4$ ir $-0,5^{\circ} \mathrm{C} / 100 \mathrm{~m}$ (vidutinis vejo greitis 3,4 ir $3,5 \mathrm{~m} / \mathrm{s}$ ), o PS storis - atitinkamai $111,9 \mathrm{ir}$ $126,2 \mathrm{~m} . \mathrm{KD}_{10}$ koncentracijos skirtumas, spejjama, galèjo susidaryti dèl vietinès taršos veiksnių Žirmūnų mikrorajone, kurie šiame tyrime neanalizuojami.

Penkiuose iš 10 DUE vyravo vidutiniškai stabilios atmosferos sąlygos (E) pagal Paskvilio stabilumo kategorijas. Keturiose iš penkių DUE vidutiniškai stabilias sąlygas lèmè anticiklonas arba jo gūbrys. Neutralias atmosferos sąlygas (3 iš 10) (D) dažniausiai lèmė mažų gradientų laukas. Stabiliausios atmosferos sąlygos (II ir VII) susidarè atitinkamai mažų gradientų slègio lauke ir ciklono šiltajame sektoriuje.

\section{HORIZONTALI PERNAŠA}

Dažniausiai pasikartojusios atgalinès dalelès trajektorijų kryptys buvo šiaurès (2) (2 pav.), pietų
(2) ir pietvakarių (2). Likusių DUE laikotarpiais (4) nustatyta skirtingos vyraujančios kryptys: rytų, pietryčių, vakarų ir šiaurès vakarų. Nei karto nenustatyta dalelès pernašos kryptis iš šiaurès rytų. Penkiuose iš 10 atvejų (II, III, VIII, IX, X) ADT kryptị lèmé mažų gradientų laukas aukštesnio slègio centre. Keturis iš 10 atvejų (I, IV, V, VI) šią kryptị lémé aukšto slègio sritis arba anticiklono gūbrys, o likusị atveji - ciklono šiltasis sektorius (VII).

$500 \mathrm{hPa}$ aukščio laukas penkiuose iš 10 (IV, VI, VIII, IX, X) epizodų atitinka aukštuminio slènio pietinę periferiją virš Pietryčių Lietuvos teritorijos. Keturiuose iš penkių šių epizodų oro temperatūra $850 \mathrm{hPa}$ lygyje yra žemesnè už $-10{ }^{\circ} \mathrm{C}$ (IV, VI, VIII, X). Kitų epizodų metu vyravo aukštuminiai anticiklonai (vakarinè periferija) arba jo gūbrys (šiaurinè periferija) (I, II, III, VII) bei drègnos oro masès (RH > $70 \%$ ) (II, III, VII), išskyrus E epizodą, kai virš Lietuvos nustatyta aukštuminio ciklono rytinè periferija. V epizode virš Lietuvos buvo aukštuminis ciklonas.

Atgalinès dalelès trajektorijai modeliuoti taikytos trys skirtingos reanalizès. Jos parodè skirtingus išvesties duomenis $925 \mathrm{hPa}$ lygyje. Keturiuose (III, V, VIII, X) iš 10 epizodų visų trijų

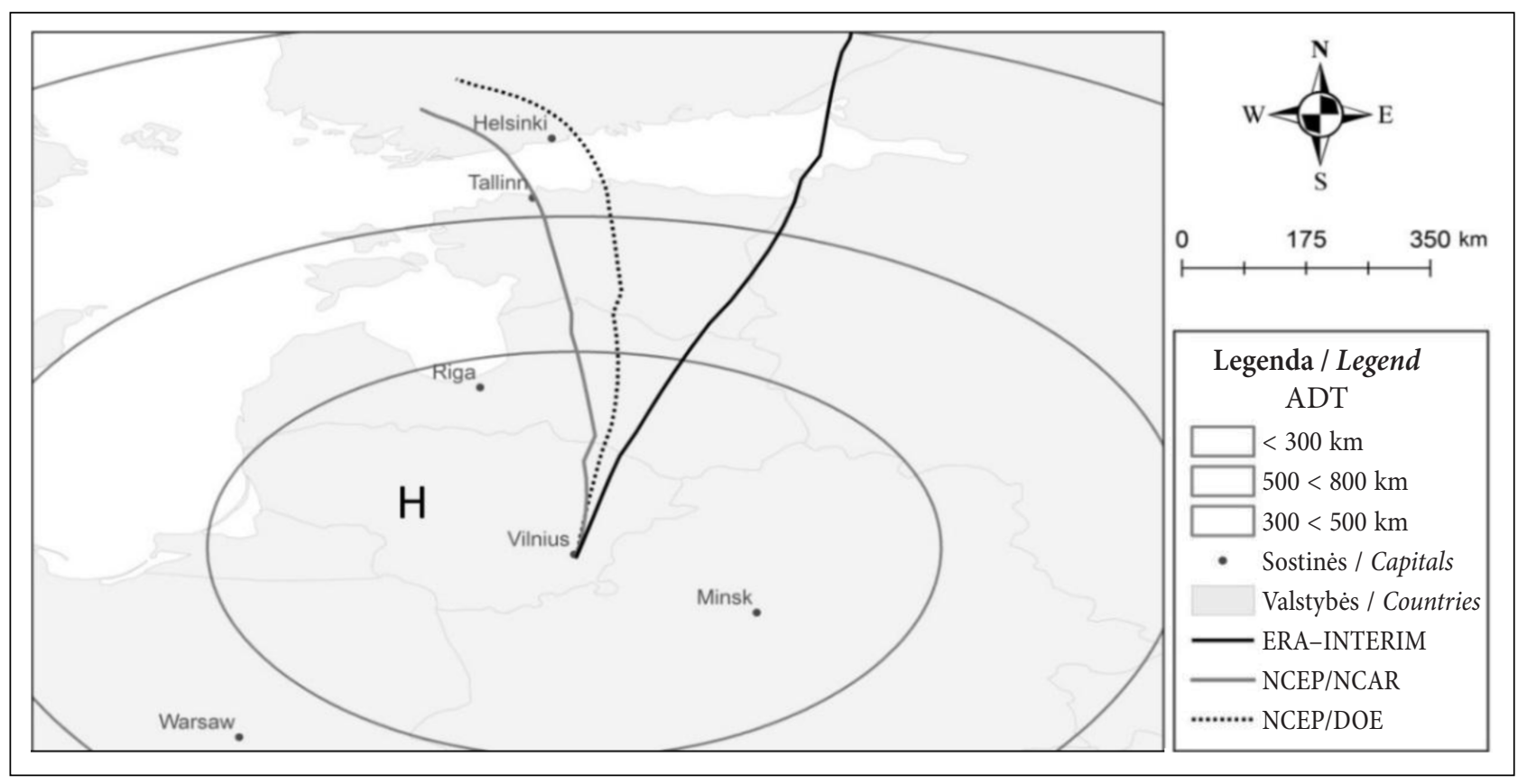

2 pav. 30 val. trukmės trajektorija (ADT) 925 hPa lygyje iki Vilniaus V situacijoje naudojant skirtingu pakartotinès analizès (ERA-Interim, NCEP/NCAR ir NCEP/DOE) duomenis. $\mathrm{H}$ - anticiklono centras

Fig. 2. 30 hours length backward particle trajectory to Vilnius using different reanalysis data (ERA-Interim, NCEP/ NCAR and NCEP/DOE) during V episode. H - center of anticyclone 
reanalizių ADT kryptys sutapo ir vizualiai mažai skyrèsi (3 pav.). Nustatytos ADT kryptys telpa 90-225 rumbuose. Tokiais atvejais laikoma, kad vyraujantys srautai pasižymèjo vienalytiškumu ir santykinai dideliu greičiu. Likusiuose $60 \%$ epizodų bent viena iš trijų ADT naudojamų reanalizių lèmé skirtingą trajektorijos kryptį. Šiose situacijose išryškeja silpnas ryšys tarp ERA ir NN1, ir NN2 reanalizių. Penkiuose iš šešių epizodų ERA atgalinès dalelès kryptis nesutapo tarp NN1 ir NN2 12,5 \%. Tik B epizode nustatyti skirtumai tarp NN1 ir ERA bei NN2 trajektorijų: vyraujanti NN1 kryptis buvo šiaurès, o NN2 ir ERA - kintančios krypties, šiaurès vakarų ir šiaurès.

Didžiausi $\mathrm{KD}_{10}$ ribinių koncentracijų viršijimo epizodai buvo du: I ir X. Abiejuose epizoduose vyravo vidutiniškai stabilios atmosferos sąlygos, tačiau nustatytas skirtingas TI gradientas - stipresné inversija susidare I laikotarpiu, $\Gamma=-0,9^{\circ} \mathrm{C} / 100 \mathrm{~m}$. I epizode buvo stiprus anticiklonas, kurio centras virš Baltarusijos ir Lietuvos (4 pav.), o X epizode vyravo mažų gradientų slégio laukas.

Dauguma iš analizuotų ADT trajektorijų, kurių galinis taškas sutampa su $1000 \mathrm{hPa}$ lygiu, savo kelyje kirto paklotini paviršių arba buvo per daug arti jo, todèl trajektorijos kryptis ir ilgis, manoma, dèl trinties ì paviršių nustatyti netiksliai. Šiame standartiniame lygyje buvo analizuoti tik keturi ADT. Trijuose iš keturių epizodų (II, VIII, X) ADT kryptis nesutapo su 925 hPa lygio trajektorijomis. ADT krypčių skirtumai - 12,5\%. Vieninteliame I epizode (4 pav.) ERA ADT kryptis $1000 \mathrm{hPa}$ lygyje sutapo su NN1, $925 \mathrm{hPa}$ lygyje su NN2 ir $1000 \mathrm{hPa}$ lygyje su NN1 trajektorijų kryptimis. Nesutapimas buvo nustatytas tarp ERA ADT krypčiu $1000 \mathrm{hPa}$ ir $925 \mathrm{hPa}$ lygiuose. Šiuose epizoduose NN1 ir NN2 trajektorijos buvo pietų krypties, o ERA $925 \mathrm{hPa}$ trajektorija vaizdavo besikeičiančią, vietinès kilmès mažai judrią oro pernašą.

Trumpiausios atgalinès dalelès trajektorijos ( $<300 \mathrm{~km}, \mathrm{~S}$ kategorija) nustatytos I ir VII epizoduose. I laikotarpiu buvo užfiksuota pati didžiausia $\mathrm{KD}_{10}$ koncentracija - $172,4 \mu \mathrm{g} / \mathrm{m}^{3}$. Šiems dviems epizodams būdinga vietinès kilmès tarša. Tarpinio ilgio ADT (300-500 km, M kategorija) priklauso šeši epizodai: II ( 5 pav.), IV, VI, VIII (4 pav.), IX ir X. Šiems epizodams būdinga regioninio masto tarša, atkeliavusi iš kaimyninių valstybių, taip pat nustatyta silpnos TI $(\Gamma=-0,4--0,9)$, išskyrus II epizodą, kai $\Gamma=-2,3{ }^{\circ} \mathrm{C} / 100 \mathrm{~m}$. Šiems epizodams būdingos mažesnès $\mathrm{KD}_{10}$, kurios tris kartus

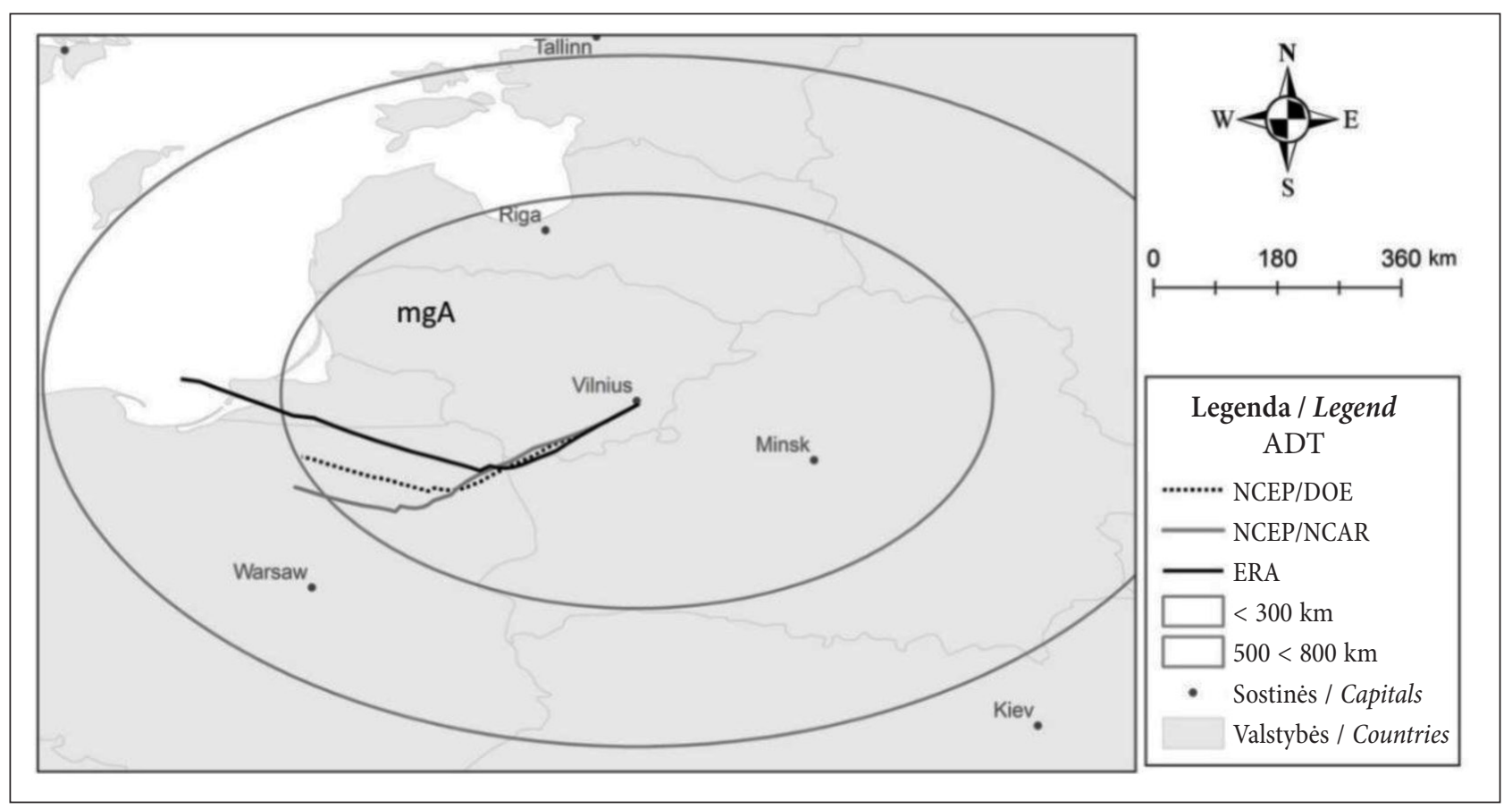

3 pav. 30 val. trukmès trajektorija (ADT) 925 hPa lygyje iki Vilniaus VIII situacijoje naudojant skirtingų pakartotinès analizès (ERA-Interim, NCEP/NCAR ir NCEP/DOE) duomenis. mgA - mažų gradientų slègio laukas

Fig. 3. 30 hours length backward particle trajectory to Vilnius using different reanalysis data (ERA-Interim, NCEP/ NCAR and NCEP/DOE) during PPE episode VIII. mgA - shallow high-pressure gradient field 


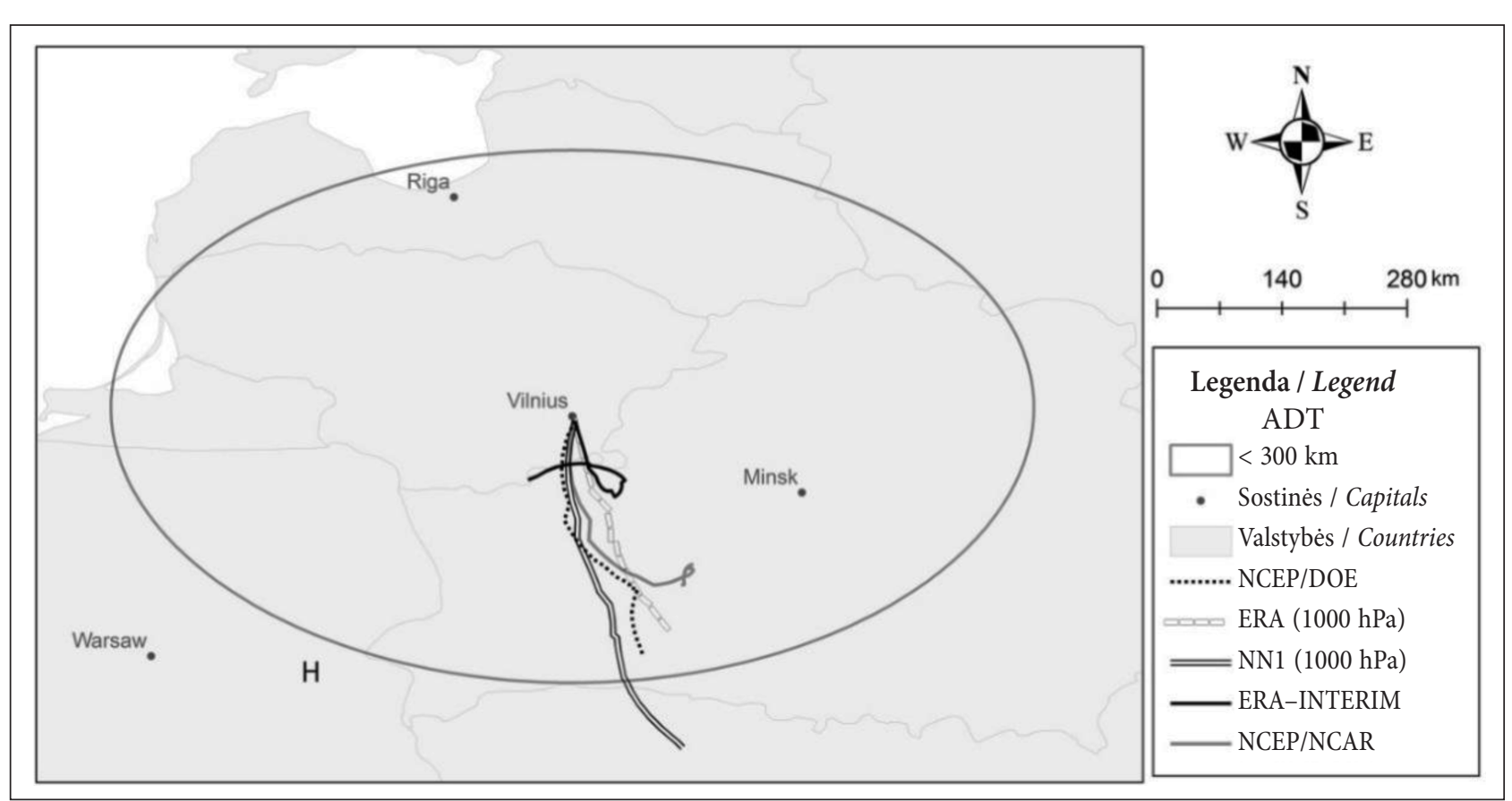

4 pav. 30 val. trukmès trajektorija (ADT) 925 hPa lygyje iki Vilniaus I situacijoje naudojant skirtingu pakartotinès analizès (ERA-Interim, NCEP/NCAR ir NCEP/DOE) duomenis. $\mathrm{H}$ - anticiklono centras

Fig. 4. 30 hours length backward particle trajectory to Vilnius using different reanalysis data (ERA-Interim, NCEP/ NCAR and NCEP/DOE) during PPE episode I. H - centre of anticyclone

neviršija leistinos normos, išskyrus X epizodą. Ilgiausios ADT viršija $500 \mathrm{~km}$ (L kategorija) ir jai priskirti III ir V epizodai. Abejais atvejais kai kuriose oro kokybės tyrimų stotyse buvo užfiksuotos maksimalios $\mathrm{KD}_{10}$ koncentracijos, kurios viršijo leistiną normą tris kartus.

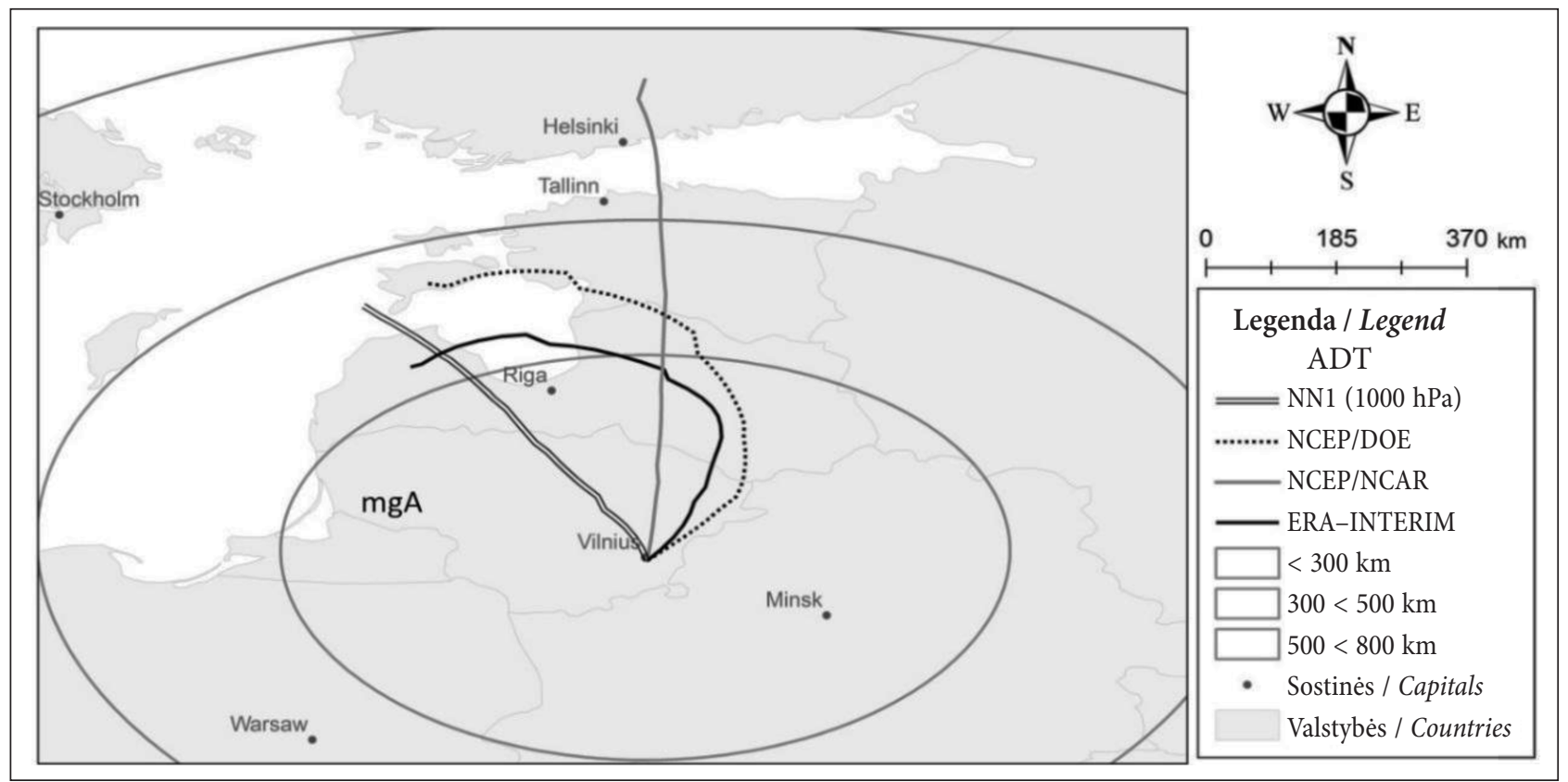

5 pav. 30 val. trukmès trajektorija (ADT) 925 hPa lygyje iki Vilniaus II situacijoje naudojant skirtingu pakartotinès analizès (ERA-Interim, NCEP/NCAR ir NCEP/DOE) duomenis. mgA - mažų gradientų slègio laukas

Fig. 5. 30 hours length backward particle trajectory to Vilnius using different reanalysis data (ERA-Interim, NCEP/ NCAR and NCEP/DOE) during PPE episode II. $m g A$ - shallow high-pressure gradient field 


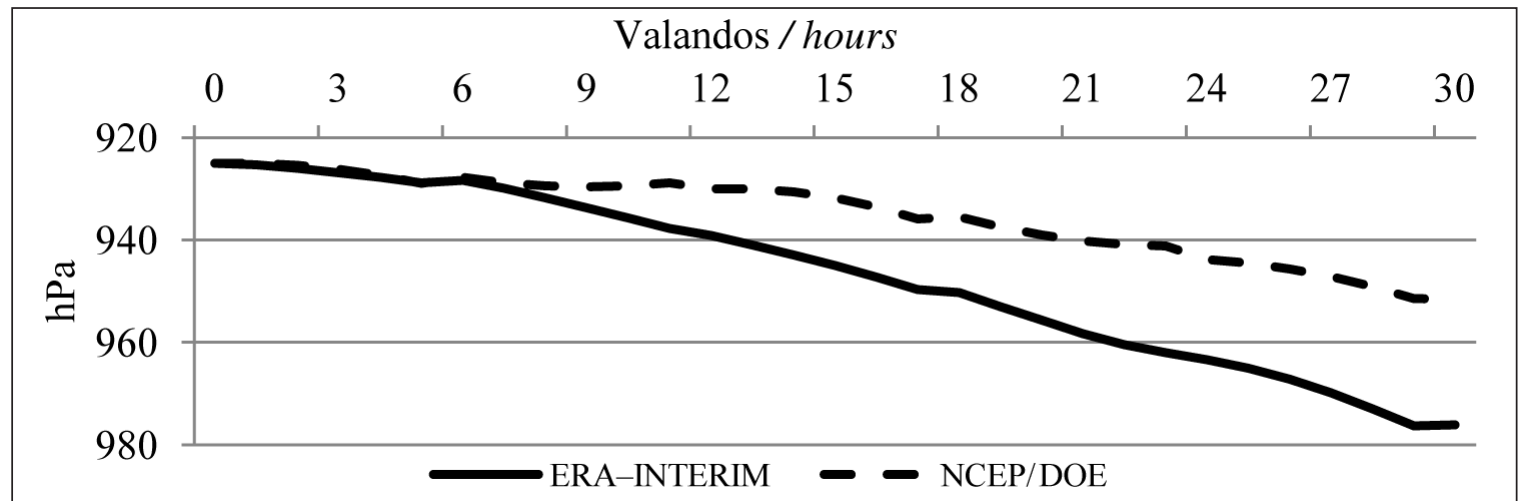

6 pav. 30 val. trukmės vertikali atgalinè dalelès trajektorija (ADT) 925 hPa lygyje iki Vilniaus VIII epizode naudojant skirtingu pakartotinès analizès (ERA-Interim ir NCEP/DOE) duomenis

Fig. 6. 30 hours length vertical particle disposition on backward trajectory to Vilnius using different reanalysis data (ERA-Interim and NCEP/DOE) during VIII PPE episode

\section{VERTIKALI PERNAŠA}

Oro dalele išilgai savo kelio dažnai keičia padèti ne tik horizontaliai, bet ir vertikaliai ir dèl to gali adiabatiškai vèsti arba šilti. $925 \mathrm{hPa}$ lygio atgalinè dalelès trajektorija keturiuose (III, IV, VII, VIII) iš 10 epizodų vertikaliai leidosi ir adiabatiškai šilo. Šiose situacijoje tai paskatino pakiliųjų arba priežeminių TI susidarymą. III ir VIII epizoduose orams įtaką darè mažų gradientų slègio laukas, o IV ir VII epizoduose - anticiklonas bei ciklono šiltasis sektorius. Visose šiose situacijose susidare priežeminès oro temperatūros inversijos. Galingiausia TI buvo susidariusi VII epizode, $\Gamma=-1,5^{\circ} \mathrm{C} / 100 \mathrm{~m}$.

Didžiausi vertikalūs oro dalelès pokyčiai nustatyti VIII epizode ERA trajektorijoje - $51 \mathrm{hPa} /$ 30 val. ERA, NN1 ir NN2 vertikali dalelès judèjimo kryptis sutapo ir atitiko žemyneigius oro srautus. Skyrèsi tik vertikalaus oro judejjimo greitis per 30 valandų. Didžiausias vertikalios oro dalelès gradientas nustatytas ERA trajektorijoje, kai NN1 - $14 \mathrm{hPa} / 30$ val. ir NN2 - $26 \mathrm{hPa} / 30$ val. (neparodyta) (6 pav.).

II ir IX epizoduose vertikali dalelès trajektorija nesutapo naudojant skirtingas pakartotinès analizès duomenis. Abiejuose epizoduose NN1 trajektorijos kilo, o NN2 - leidosi. ERA trajektorijų vertikalūs pokyčiai neviršijo $20 \mathrm{hPa} / 30$ val. amplitudès, kurie atitinka galimą trajektorijos tikslumo paklaidą. $1000 \mathrm{hPa}$ lygyje trijuose epizoduose (I, II, VII) vertikalios skirtingų reanalizių trajektorijos tarpusavyje prastai derejo, todèl galima teigti, kad šiame lygyje skirtingose reanalizèse buvo labai įvairios trinties, paribio sluoksnio ir kitų judejjimą veikiančių veiksnių charakteristikos.

\section{IŠVADOS}

1. Mažiau nei pusejje analizuotų didelio oro užterštumo epizodų skirtingų pakartotinès analizès atgalinès dalelès trajektorijų kryptys sutapo. Tai rodo vyravus labai vienalytị oro srautą. $60 \%$ epizodų nustatytas silpnas ryšys tarp skirtingų pakartotinių analizių - dalelès trajektorijos kryptis nesutapo $12,5 \%$.

2. Mažiau nei pusejje analizuotų didelio oro užterštumo epizodų $925 \mathrm{hPa}$ lygyje pagal atgalinę dalelès trajektoriją oro dalelè adiabatiškai leidosi, ir vyravo žemyneigiai oro srautai, kurie paskatino temperatūros inversijų susiformavimą. Didžiausias $925 \mathrm{hPa}$ lygyje oro dalelès vertikalus greitis iš ERA-Interim duomenų nustatytas VIII epizode $-51 \mathrm{hPa} / 30$ val.

3. Visais didelio oro užterštumo epizodais Vilniuje rytinemis valandomis (00-06 val.) nustatytos priežeminès temperatūros inversijos $\left(\Gamma>-0,4{ }^{\circ} \mathrm{C} / 100 \mathrm{~m}\right)$.

4. Stipriausios priežeminès inversijos didelio oro užterštumo epizodais atitiko (pagal Paskvilio stabilumo klases): labai stabilias (2 epizodai), silpnai stabilias (5 epizodai) ir neutralios atmosferos sąlygas (3 epizodai).

5. Devyniuose iš 10 tirtų epizodų virš Pietryčių Lietuvos nustatytas anticikloninis laukas, kuris 
dar suskirstytas ị mažų gradientų slègio lauką (5 epizodai) ir aukšto slègio sritis (centrinè dalis, 4 epizodai; vienas epizodas susietas su ciklono šiltuoju sektoriumi (VII)). Pusè analizuojamų epizodų susidarè dèl aukštuminio slènio ịtakos. Trijuose iš 10 epizodų vyravo aukštuminis anticiklonas.

6. Kietųų dalelių $\left(\mathrm{KD}_{10}\right)$ paros koncentracija daugiau negu tris kartus viršijo leistiną ribinę vertę dviejuose epizoduose (I ir X). Ir vienu, ir kitu vyravo vidutiniškai stabilios atmosferos sąlygos santykinai sausoje oro maseje (30-60\%).

Gauta 20181129

Priimta 20190122

\section{LITERATŪRA}

1. Ahrens D. 2008. Meteorology Today: An Introduction to Weather, Climate, and the Environment. Belmont: Brooks/Cole.

2. Aplinkos apsaugos agentūra. Oro kokybès statistika ir duomenys. http://oras.gamta.lt/cms/ index?rubricId=3c923924-6bb5-42dc-89ba55a91f603103 (žiūrèta 201811 10).

3. Barras V., Simmonds I. 2009. Observation and modelling of stable water isotopes as diagnostics of rainfall dynamics over south-eastern Australia. Journal of Geophysical Research. 114.

4. Bukantis A., Rimkus E., Stankūnavičius G. 2003. Atmosferos taršos kaitos urbanizuotose teritorijose prognozè. Geografijos metraštis. 36(2): 7-19.

5. Czernecki B., Półrolniczak M., Kolendowicz L., Marosz M., Kendzierski S., Pilguj N. 2016. Influence of the atmospheric conditions on $\mathrm{PM}_{10}$ concentrations in Poznań, Poland. Journal of Atmospheric Chemistry. 74: 115-139.

6. Chandrasekar A. 2010. Basics of Atmosphere Science. PHI Learning Private Limited.

7. Dee D. P., Uppala S. M., Simmons A. J., Berrisford P., Poli P., Kobayashi S., Andrae U., Balmaseda M. A., Balsamo G., Bauer P., Bechtold P., Beljaars A. C. M., van de Berg L., Bidlot J., Bormann N., Delsol C., Dragani R., Fuentes M., Geer A. J., Haimberger L., Healy S. B., Hersbach H., Hólm E. V., Isaksen L., Kållberg P., Köhler M., Matricardi M., McNally A. P., Monge-Sanz B. M., Morcrette J.-J., Park B.-K., Peubey C., de Rosnay P., Tavolato C., Thépaut J.-N., Vitart F. 2011. The ERA-Interim reanalysis: configuration and performance of the data assimilation system. Quarterly Journal of the Royal Meteorological Society. 137: 553-597.

8. Fortelli A., Scafetta N., Mazzarella A. 2016. Influence of synoptic and local atmospheric patterns on $\mathrm{PM}_{10}$ air pollution levels: a model application to Naples (Italy). Atmospheric Environment. 143: 218-228.
9. Galvonaitė A., Valiukas D., Kilpys J., Kitrienè Z., Misiūnienè M. 2013. Lietuvos klimato atlasas. Vilnius: Lietuvos hidrometeorologijos tarnyba prie Aplinkos ministerijos.

10. Godłowska J., Hajto M. J., Tomaszewska A. M. 2015. Spatial analysis of air masses backward trajectories in order to identify distant sources of fine particulate matter emission. Archives of Environmental Protection.

11. Hondula D. M., Sitka L., Davis R. E., Knight D. B., Gawtry S. D., Deaton M. L., Lee T. R., Normile C. P., Stengera P. J. 2009. A back-trajectory and air mass climatology for the Northern Shenandoah Valley, USA. International Journal of Climatology.

12. Ioannidou L., Yau M. K. 2008. Climatology of the Northern Hemisphere winter anticyclones. Journal of Geophysical Research. 113.

13. Kalnay E., Kanamitsu M., Kistler R., Collins W., Deaven D., Gandin L., Iredell M., Saha S., White G., Woollen J., Zhu Y., Leetmaa A., Reynolds B., Chelliah M., Ebisuzaki W., Higgins W., Janowiak J., Mo K. C., Ropelewski C., Wang J., Jenne Roy, Joseph Dennis. 1996. The NCEP / NCAR 40Year Reanalysis Project. Bulletin of the American Meteorological Society. 77(3): 437-472.

14. Kanamitsu M., Ebisuzaki W., Woollen J., Yang S.-K., Hnilo J. J., Fiorino M., Potter G. L. 2002. NCEP-DOE AMIP-II Reanalysis (R-2). Bulletin of the American Meteorological Society. 83: 1631-1643.

15. Law R. M. 1993. Modelling the Global Transport of Atmospheric Constituents. PhD thesis, School of Earth Sciences, The University of Melbourne.

16. Lietuvos Respublikos aplinkos oro apsaugos istatymas Nr. 98-2813. Pirmasis skirsnis. Bendrosios nuostatos.

17. Li J., Chen H., Zhanqing L., Wang P., Maureen C., Fan X. 2014. Low-level temperature inversions and their effect on aerosol condensation nuclei concentrations under different large-scale synoptic circulations. Advances in Atmospheric Sciences. 32: 898908.

18. Manahan S. E. 2000. Environmental Science, Technology, and Chemistry. Environmental Chemistry. Boca Raton: CRC Press LLC.

19. Nemuc A., Taliunu C., Belegante L., Ngo R., Derognat C. 2012. The Boundary layer height and entrainment zone assessment from lidar, meteorological land forecast model. Proceedings of the 9th International Symposium on Tropospheric Profiling.

20. Matthaios V. N., Athanasios G. Triantafyllou, Petros Koutrakis. 2016. $\mathrm{PM}_{10}$ episodes in Greece: Local sources versus long-range transport-observations and model simulations. Journal of the Air \& Waste Management Association.

21. Oro dalelès trajektorija. http://www.cycstats.org/trajectories/trajhome.htm (žiūrèta 20181120 ).

22. Paskvilio stabilumo klasès. https://ready.arl.noaa. gov/READYpgclass.php/ (žiūrèta 201811 20). 
23. Pei H., Shiliang W. 2016. Long term changes in extreme air pollution meteorology and the implications for air quality. Scientific Reports.

24. Perrin G., Simmonds I. 1995. The origins and characteristics of cold air outbreaks over Melbourne. Australian Meteorological Magazine. 44: 41-59.

25. Rimkus E., Bukantis A., Stankūnavičius G. 2006. Meteorologinių veiksnių poveikis KD2.5 aerozolio koncentracijos kaitai Preiloje. Geografija. 42(2): 56-64.

26. Royal Netherlands Meteorological Institute (KNMI). Archyvines sinoptines schemos. http:// www.knmi.nl/nederland-nu/klimatologie/ (žiūrèta $20181120)$.

27. Schnelle B. K., Brown A. C. 2002. Air Pollution Control Technology Handbook. The Mechanical Engineering Handbook Series. CRC Press LLC, 2000 N.W.

28. Sillman S., Samson P. J. 1995. Impact of temperature on oxidant photochemistry in urban, polluted rural, and remote rnvironments, Journal of Geophysical Research. 100: 11497-11508.

29. Skaitmenines vertikalios atmosferos duomenys. https://ready.arl.noaa.gov/READYamet.php (žiūrèta 20181120 ).

30. Stull R. 2017. Practical Meteorology: An Algebrabased Survey of Atmospheric Science. Version1.02b. University of British Columbia. $940 \mathrm{p}$.

31. Šaulienè I., Veriankaitè L. 2006. Application of backward air mass trajectory analysis in evaluating airborne pollen dispersion. Journal of Environmental Engineering and Landscape Management. XIV(3): 113-120.

32. Trajektoriju imitaciju tinklalapis. https://www.esrl. noaa.gov/psd/cgi-bin/data/trajtool/traj.pl (žiūrèta 201811 10).

33. Veriankaitè L. 2010. Žiedadulkiu koncentracija ore: cirkuliaciniai ir fenologiniai aspektai: daktaro disertacija. Vilnius.
Dainius Frišmantas, Gintautas Stankūnavičius

\section{STUDY OF WEATHER CONDITIONS DURING STRONG AIR POLLUTION EPISODES IN VILNIUS}

Sum mary

The study deals with ten strongest air pollution episodes in Vilnius and their relationship with meteorological conditions. The main task of the study was an assessment of air flow impact on daily concentration of particulate matter $\left(\mathrm{PM}_{10}\right) . \mathrm{PM}_{10}$ data are available at the Lithuanian Environment Protection Agency. Airflow was assessed using 30-hour backward trajectory of air particle (horizontal and vertical) to Vilnius based on data of three different reanalysis: ERA-Interim, NCEP/NCAR, and NCEP/DOE. The impact of meteorological conditions on pollution was assessed analysing the changes in the atmospheric stability criteria: boundary layer depth, the strength of surface temperature inversions, and the intensity of vertical mixing. These characteristics are available at NOAA Air Resources Laboratory Archived Meteorology website.

These 10 selected episodes were detected in the period from 2005 to 2016. The selected height of the endpoint of the backward trajectory was within the boundary layer 1000 and $925 \mathrm{hPa}$. All trajectories were classified into three appropriate ranges of distances: local $(<300 \mathrm{~km})$, regional $(300-500 \mathrm{~km})$, and remote $(>500 \mathrm{~km})$.

In 4 of the 10 episodes the backward trajectories based on all three reanalyzes, ERA-INTERIM, NCEP/NCAR, NCEP/DOE, showed a homogeneous airflow. Five out of 6 remaining cases revealed a weak connection between ERA-INTERIM and NCEP/NCAR and NCEP/DOE trajectories (differences reached 12.5\%), and one case had the longest backward trajectory extending more than $800 \mathrm{~km}$ per $30 \mathrm{~h}$.

The most typical directory of the backward trajectory was from north, south and southwest. The shallow highpressure gradient field was the typical influencing surface pressure pattern for 5 episodes, high-pressure area (centre) for 4 episodes, and the warm sector of cyclone for one episode.

Keywords: $\mathrm{PM}_{10}$, air pollution episodes in Vilnius, backward air particle trajectory, atmospheric stability, temperature inversion 